\title{
The Development of Digital Competencies through Video Games
}

\author{
Verónica Marín-Díaz ${ }^{1} \&$ Jorge F. Figeroa Flores ${ }^{2}$ \\ ${ }^{1}$ Departament of Education, Faculty of Education, University of Córdoba, Spain \\ ${ }^{2}$ Univerisdad del Este, Puerto Rico \\ Correspondence: Verónica Marín-Díaz, Faculty of Education, Avda. San alberto Magno s/n, 14004-Córdoba, Spain. \\ Tel: 349-5721-2617. E-mail: vmarin@uco.es
}

Received: July 31, 2014 Accepted: August 29, $2014 \quad$ Online Published: September 21, 2014

doi:10.5430/wjss.v2n1p32 URL: http://dx.doi.org/10.5430/wjss.v2n1p32

\begin{abstract}
Using today's video games in the classroom is beginning to become a reality. It's perceived as a way to approach technology from early childhood and drawn as a complement to the curriculum development of the young. This new perspective is becoming a trend in the mind of the teachers, who are gradually incorporating it into the classroom as a tool. This article presents the results of an experience carried out with students from elementary school. The overall objective was to determine whether video games could become an additional tool in curriculum development for children during this educational stage, as seen from the perspective of future teachers doing initial elementary education training, and if its integration would determine behavioral patterns towards the development of the socialization process. A Likert scale questionnaire was constructed in response to an ex post facto research model. The initial results obtained demonstrated the willingness of the current students enrolled in the education program to employ video games in their classrooms, after a didactic introduction to the use was given, in addition to confirming the hypothesis in regards to socialization, pointing which are behavioral modulators, stereotypes and peer group views, among others aspects.
\end{abstract}

Keywords: ITC, video games, digital competence, students

\section{Introduction}

The first boom of gaming could be placed around the 1980's. This was characterized as a roller coaster in regards to success-failure relates. At the beginning of that decade, the company Atari was in crisis given to the market saturation of gaming consoles. The first re-emergence of this medium happens when the company Nintendo Entertainment System put on the market an 8-bit console that revolutionized the industry. Another event that shaped this decade and could be considered the final push for a new start is the appearance of the video game Tetris, along with the start of the Mario saga in 1985 and the Legend of Zelda, both from the Nintendo company.

At that time, specifically in 1985, the video game company SEGA was born and launches the first game of the Sonic collection, which even today continues to develop. A new beginning and splendor can be situated in the 1990s. This was in part by the great competition established by four companies involved in this type of leisure: Nintendo, Sony, Sega and Microsoft. A decade later this rapid rise continued, due to different factors, including the proliferation of video games created under the Internet.

This development throughout history has brought questioning by linking aspects of leisure and entertainment. Such as the assumption of traditions that still survive and will be affected based on the reality of the future of the XXI century, characterized by great technological development. Another clear example of this is found in the fall of digital television versus video game, both supported on a game console, such as a computer, playing online or in a group, or individually.

All this has generated different voices that are gone in favor of raising an element that may well be understood as a disruptive behavior well regarded as a generator of new models or learning systems. That's where we locate this article, to make the reader see whether video games in general, regardless of the support system can have an educational aspect or should be relegated to the spectrum of playing time.

Thanks in part to the integration of technology to the curriculum; in education we talk about Game Based Learning 
(GBL) frequently. This type of learning, as pointed out by the team of EdTech Review (www.edtechreview.in) (2013) is a kind of teaching in which students explore the most relevant aspects of the game within a specific learning context. Examples of this kind of perspective are found in proposals like Marin, Cabero and Ramirez (2010) and Marin, and Muñoz Sampedro (2013), where the design of the training is based on the use of video games as educational resource blocks, given that it is working towards achieving a goal, through experimentation, and enhancing motivation for the learning process (Barendiegt \& Bekker, 2011).

Let's not forget the dimensions by which learning is structured including knowledge, application, identification of sport, fantasy, competition entertainment, social interaction and fun are involved during game time with video games (Kim \& Ross, 2006; Hamlen, 2011). That is why we consider it to be an adequate resource based on the reality of today's classrooms.

Since it became a trend, the talk about basic competencies in the Spanish education systems (GLSES, 1990; LOE 2006; LOMCE, 2013), and digital competence is contemplated as one of them, a stronger bond between traditional learning and information and communication technology occurred. In some cases adapting resources that at a certain point were not contemplated such as video games. The new conception of learning is not only focused on skills or competencies but based on how the learner learns to reclaim, redefine and reuse the information obtained through information and communication technologies or learning called the three R or A3R. Bu this means that today's students also learn five basic aspects: access, analyze, evaluate, create and reflect to take action (Hobbs, 2010) toward curriculum practice.

In this case until its appearance in the 50s in the recreational area of youth and adolescents, was revolutionary because the only technological tool we had at that time in homes and schools that was socially accepted was television (Marin, 2006; 2012a), considering that share a look, both us into an unreal world of fiction that helps us evade reality, coming to unleash our emotions. In this sense, families never questioned the positive or negative for the human behavior. But video games continued to be assess and compared toward values and counter values that are very present in our daily lives such as machismo, eroticism, violence, competitiveness, consumerism, empathy, companionship, responsibility, participation in decision-making, etc.

We share Gros (2004) and Raña (2003) that video games in general and those with educational content in particular, can be understood as an element that is introduced to the boys and girls, as well as adolescents for cultural technology beyond a simple playful perspective by design and nature presented. Moreover, do not forget that we view them as "something that can directly influence their attitudes, behaviors and cognitive structures-with knowledge-building, any more than they can do television programs, implying procedurally to subjects "(Del Moral \& Villaluestre, 2014: 92). Therefore, we advocate enhance and draw attention to the advantages or benefits rather than disadvantages or handicaps It is true that throughout its history has had supporters and detractors, which have enhanced these issues-violence free excessive erotic scenes, inciting substance use, distorted image of women, sedentary behavior, obesity, poor nutrition, social isolation ... (Marín \& Maldonado, 2014). However, we support a constructivist view of using them and consider aspects such as exercise allowing fantasy and imagination therefore able to travel and / or belong or be part of other worlds, repeating behaviors to advanced, achieving a command of both social skills and emotional, physical and psychological, to encourage increased attention, motivation for learning, behavior modification, learning by doing and active learning (GBL), appreciate cultural values different, the development of critical thinking, construction and reconstruction of knowledge, collaboration, the ability to react to adverse situations, the ability to solve problems, the development of spatial skills, effective use of information, etc.. (Killiemuir \& McFarlone, 2003; Marin \& Garcia, 2005; Barendiegt \& Bekker, 2011; Watson, Christopher \& Harris, 2011; Contreras, 2013; Garrido, 2013; Alamri Hassan Hassain, Al-Qurishi, Aldukhayyit \& Hossain, 2014 , Mortaraa, Catalanoa, Bellottib, Fiuccic, Houry-Panchettid \& Petridise, 2014), are cardinal elements to enhance effective learning through video games. Moreover, the report in 2012 by the Spanish Association of Distributors and Publishers Entertainment Software (aDeSe), on the use of video games in education, noted a significant increase in the use by teachers in classrooms, with $30 \%$ of the population of teachers and professors consulted. In that study, participants indicated that teachers use as curricular element or resource has allowed the students to motivate knowledge were more difficult to assimilate and / or understand them, so it also reflected that attract your attention a particular object, in this case-curricular content, significantly increased their retention and their mental capacity, the classroom became a more dynamic, active, attractive and participatory space. In this line we find the results of research conducted by Williamson in 2009, in which British teachers were consulted and 55\% included the dynamics of the classroom and $60 \%$ in a positive position to introduce. Both, students and teachers are likely to see the educational use. "The use of video games and digital games at the educational level need to start from the relationship between the message they emit and the universe, and recreate the player who must also know how to interpret, but behold a handicap, sometimes this universe is well-played, well not know the code well icon for not knowing the meaning of the message itself "(Marin, 
2012b: 194). We must be aware that by any recreational activity we learn, but that learning is an educational character that must make sense, have a didactic structure, be linked to a series of objectives and goals to achieve, develop skills through a battery activities linked to specific content of school curriculum. Also that the teacher plays a cardinal role, if priority, since the extent that this provides for resources from an open perspective these can be used as element of the classroom, making them not a distorter methodological dynamics employed daily, so when the students have internalized the not think that day is a day that they will not provide content but is a more fun way to learn. An example of this is found in the commitment made by the University of Berkeley in California, where it offer to the students a course in which the working tool is the Starcraft game. To enroll in this course basic knowledge of calculus and differential equations is required. Since it is a strategy game in real time allows.

The aim to achieve with students is the application of simulation situations to real life through the development of critical thinking, decision-making in extreme situations. Benefits of teaching or educational application of video games into the classroom every day and are dormant. In research conducted by Quintanal (2013: 419), with high school students in the subjects of Physics and Chemistry, proposes the development of curriculum of that subject through mini games, they "increase student motivation and the strengthening of their autonomy, self-confidence and self-esteem, contributes to meet the educational objectives in terms of content, skills (especially social) and values, encourages consideration of rates of learning, teamwork and progress of the intellectual powers, develops and enhances student information and communication skills and consideration of them as creators of scientific content to share with their peers.

\section{Methodology}

The spark plug questions by which this research was started included: Could video games modulate the behavior of young people today? Does an educational approach is needed? Can they be used as resources in the classroom for the development and understanding of the curriculum content?

From these we have established the following work objectives:

1. To determine that video games are elements that can modulate behaviors, affect belief systems, values, attitudes and skills.

2. To clarify if video games are a technological resource that could help in the comprehension of curricular content.

3. To determine whether methodological systems must use them in the classroom to improve the classroom climate/atmosphere.

4. To determine whether education should look at them from an educational and pedagogical perspective.

\subsection{Data Collection Instrument}

To collect the data, the survey method was used, and within this questionnaire technique. To verify that the instrument was going to measure what was intended to achieve thru the objectives and responding to the questions of departure it was tested for validity and reliability.

Finally, it consisted of 23 items, with different response scales grouped in two dimensions. So items 1 to 14 form part of dimension 1 called "Attitude towards video games." These had a nominal response option type: yes, no, do not know do not answer. As for the second, which has been called "Video games and elementary classroom" has been formed by 9 items with a response scale Likert scale, where 1 corresponds to strongly disagree and 5 strongly agree.

Regarding to the validity, it was submitted to a panel of experts. This selected group of educators met the following criteria: five years of university teaching experience, video game users, use technology in their daily classroom activities, teach undergraduate students in an elementary education program. Finally, eight educators were selected, with five men and three women, of which everyone taught in different faculties of Education from various universities from Spain. Four of them were from Universidad de Córdoba, two from Universidad de Granada and two from Universidad de Málaga. The evaluation by the panel of experts resulted very positive due in part to the recommendation of the grouping of items on the two dimensions in which they were finally distributed because they weren't at first. To determine the reliability of the instrument a Cronbach's Alpha test was done. The test conducted on the entire questionnaire showed reliability by obtaining 0.864 which according to Matthew (2012) can be considered high.

Then it was considered to conduct an exploratory analysis between the scale variables proposed in the instrument in the 
pursuit of giving validity and to find the latent factors that exist; for this purpose, and as indicated by Marín García (2011), we conducted the following analysis: descriptive statistics for the variables and bivariate correlations with the following results. Regarding the descriptive statistics, as can be seen in Table 1, the scale variables studied are between 88 and 87 cases; the least in most of them is 1 and the maximum 5, with the same extreme values of the proposed and available. Compared with the average, it shows that most values are between 3.44 and 3.95 one also reaches the value of 4 . In conclusion, there is considerable variability (minimum and maximum values) and a moderate degree variable for use by the users surveyed (average).

Table 1. Descriptive statistics of dimension 2

\begin{tabular}{|c|c|c|c|c|c|}
\hline & $\mathrm{N}$ & Min. & Max. & M. & D.T \\
\hline $\begin{array}{l}\text { Learn to work thru cooperation and collaboration using } \\
\text { teamwork. }\end{array}$ & 88 & 1 & 5 & 3.44 & 1.113 \\
\hline Distinguish the parts of the body. & 87 & 1 & 5 & 3.55 & .899 \\
\hline $\begin{array}{l}\text { Learn the synchronicity between the upper and lower } \\
\text { member of the body. }\end{array}$ & 87 & 1 & 5 & 3.60 & .784 \\
\hline Recognize primary and secondary colors. & 88 & 1 & 5 & 3.70 & .886 \\
\hline Development of heuristic thinking (trial-error). & 87 & 2 & 5 & 3.93 & .759 \\
\hline $\begin{array}{l}\text { Autoregulation of individual learning (continuing } \\
\text { evaluation) }\end{array}$ & 88 & 1 & 5 & 3.58 & .840 \\
\hline Development of inductive thinking. & 87 & 1 & 5 & 3.64 & .807 \\
\hline Development of visual memory and retentive memory. & 88 & 2 & 5 & 4.00 & .758 \\
\hline $\begin{array}{l}\text { Understand the concept of success, failure, up-down, } \\
\text { inside-out, front-back. }\end{array}$ & 88 & 1 & 5 & 3.95 & .843 \\
\hline
\end{tabular}

In regards to the Pearson $r$ test for determining the existence of correlation between the items of the second dimension, in Table 2 we can see the results for the video games and elementary classroom dimension.

Table 2. Correlations for the video games and the elementary classroom dimension

\begin{tabular}{|c|c|c|c|c|c|c|c|c|c|c|}
\hline & & Item 15 & Item 16 & Item 17 & Item 18 & Item 19 & Item 20 & Item 21 & Item 22 & Item 23 \\
\hline \multirow{2}{*}{$\begin{array}{c}\text { Item } \\
15\end{array}$} & $\mathrm{R}$ & 1 & .498 & .414 & .554 & .259 & .509 & .381 & .313 & .328 \\
\hline & $\mathrm{P}$ & & .000 & .000 & .000 & .015 & .000 & .000 & .003 & .002 \\
\hline \multirow{2}{*}{$\begin{array}{c}\text { Item } \\
16\end{array}$} & $\mathrm{R}$ & .498 & 1 & .566 & .673 & .292 & .435 & .374 & .249 & 335 \\
\hline & $\mathrm{P}$ & .000 & & .000 & .000 & .006 & .000 & .000 & .020 & .002 \\
\hline \multirow{2}{*}{$\begin{array}{c}\text { Item } \\
17\end{array}$} & $\mathrm{R}$ & .414 & .566 & 1 & .442 & .381 & .476 & .455 & .189 & .370 \\
\hline & $\mathrm{P}$ & .000 & .000 & & .000 & .000 & .000 & .000 & .080 & .000 \\
\hline \multirow{2}{*}{$\begin{array}{c}\text { Item } \\
18\end{array}$} & $\mathrm{R}$ & .554 & .673 & .442 & 1 & .375 & .480 & .338 & .308 & .243 \\
\hline & $\mathrm{P}$ & .000 & .000 & .000 & & .000 & .000 & .001 & .004 & .022 \\
\hline
\end{tabular}




\begin{tabular}{|c|c|c|c|c|c|c|c|c|c|c|}
\hline \multirow{2}{*}{$\begin{array}{c}\text { Item } \\
19\end{array}$} & $\mathrm{R}$ & .259 & .292 & .381 & .375 & 1 & .566 & .458 & .548 & .591 \\
\hline & $\mathrm{P}$ & .015 & .006 & .000 & .000 & & .000 & .000 & .000 & .000 \\
\hline \multirow{2}{*}{$\begin{array}{c}\text { Item } \\
20\end{array}$} & $\mathrm{R}$ & .509 & .435 & .476 & .480 & .566 & 1 & 619 & .505 & .622 \\
\hline & $\mathrm{P}$ & .000 & .000 & .000 & .000 & .000 & & .000 & .000 & .000 \\
\hline \multirow{2}{*}{$\begin{array}{c}\text { Item } \\
21\end{array}$} & $\mathrm{R}$ & .381 & .374 & .455 & .338 & .458 & 619 & 1 & .567 & .520 \\
\hline & $\mathrm{P}$ & .000 & .000 & .000 & .001 & .000 & .000 & & .000 & .000 \\
\hline \multirow{2}{*}{$\begin{array}{c}\text { Item } \\
22\end{array}$} & $\mathrm{R}$ & .313 & .249 & .189 & .308 & .548 & .505 & .567 & 1 & .486 \\
\hline & $\mathrm{P}$ & .003 & .020 & .080 & .004 & .000 & .000 & .000 & & .000 \\
\hline \multirow{2}{*}{$\begin{array}{c}\text { Item } \\
23\end{array}$} & $\mathrm{R}$ & .328 & .335 & .370 & .243 & .591 & .622 & .520 & .486 & 1 \\
\hline & $\mathrm{P}$ & .002 & .002 & .000 & .022 & .000 & .000 & .000 & .000 & \\
\hline
\end{tabular}

As shown in Table 2, and after reviewing the data we can establish that there is a relationship between all the items in this dimension, since there is bilateral significance level, both $\mathrm{ns}=0.01$ and $\mathrm{ns}=0.05$; although the relationship between these ranges, according to each item, between floor $(22 \mathrm{x}$ item $16, \mathrm{r}=0.292)$, average, labeled or marked (item $16 \mathrm{x}$ item $18, \mathrm{r}=0.673$ ) and high or very high (item $1 \mathrm{x}$ item $1, \mathrm{r}=1$ ), as categorized by Perez Garcia, Gil and Guy (2009). In conclusion, in view of the results we can see that there will be between one and two latent factors within the range of the instrument.

\subsection{Population and Sample}

The participants of this study were all current students pursuing an undergraduate degree in elementary education and taking the course "School life \& Culture of Peace". The sample is made of the students that attended the day when the instrument was administered in the classroom. The only reason to take this sample is due to the willingness of teachers of this subject to participate in the study as well as the students.

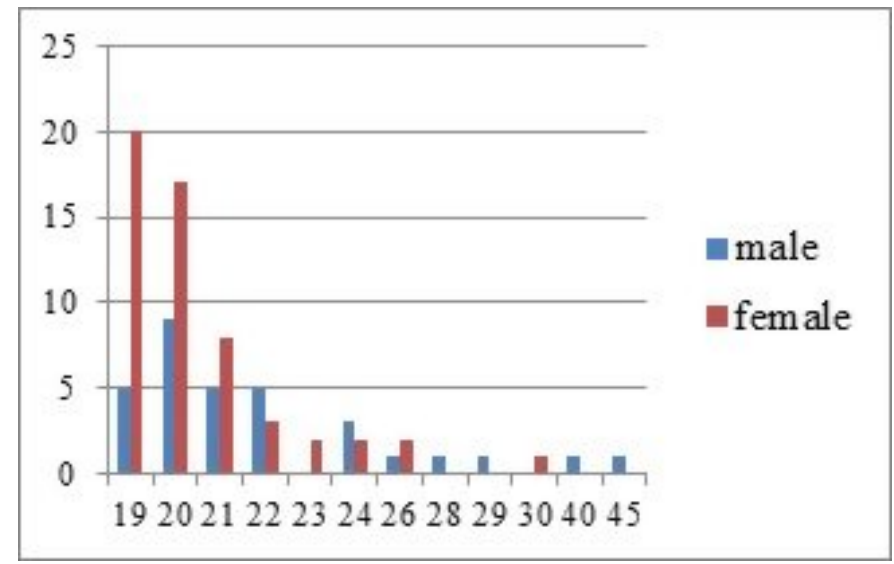

Figure 1. Gender/Age contingency

In regards to gender, the sample consisted of $63.6 \%$ men and 36.4 women. If we focus on the age variable sample is located around $20(29.9 \%)$ and 19 years (28.7), having few students within the ages over 28 years, finding in all cases 
with the presence of $1.1 \%$. In regards to the distribution of participants by gender and age the presence of women is higher in the age of 19,20,21,23, 26 and 30, while it is zero at 28,29, 40 and 45.

Regarding the results and sample obtained in frequencies and percentages (Table 3) is seen that in dimension 1 the participant likes playing games but doesn't read magazines on this subject on paper or digital format, nor read the cover of information where the video game comes. However, it is striking that although he/she likes to play it is not interested in participating in online chat or meetings nor imitating the video game characters. Significantly, they consider that video games can be educational resources without having used them in the classroom. They've used them in self-taught form, and they insist that there should be more educational oriented games. Finally, it is significant to note that most establish that spend hours playing do not reduce hours of study time.

Table 3. Attitude toward video games

\begin{tabular}{|c|c|c|c|}
\hline & $\begin{array}{l}\text { f. } / \% \\
\text { YES }\end{array}$ & $\begin{array}{l}\text { f. } / \% \\
\text { NO }\end{array}$ & $\begin{array}{c}\text { f. } / \% \\
\text { DK/NA }\end{array}$ \\
\hline \multirow[t]{2}{*}{ 1. I like to play video games } & 54 & 33 & 1 \\
\hline & $61.4 \%$ & $37.5 \%$ & $1.1 \%$ \\
\hline \multirow[t]{2}{*}{ 2. I read specialized gaming magazines } & 4 & 84 & \\
\hline & $4.5 \%$ & $95.5 \%$ & \\
\hline \multirow[t]{2}{*}{ I read thru the Internet all new related content on gaming } & 3 & 85 & \\
\hline & $3.4 \%$ & $96.6 \%$ & \\
\hline \multirow{2}{*}{$\begin{array}{l}\text { I read the classification of the game in the cover before } \\
\text { using it. }\end{array}$} & 20 & 65 & 1 \\
\hline & $22.7 \%$ & $75 \%$ & $1.1 \%$ \\
\hline \multirow{2}{*}{$\begin{array}{l}\text { I like to comment about video games with friends and } \\
\text { acquaintances }\end{array}$} & 33 & 55 & \\
\hline & $37.5 \%$ & $62.5 \%$ & \\
\hline \multirow[t]{2}{*}{ 6. I participate in forums and chats about gaming } & 2 & 84 & 2 \\
\hline & $2.3 \%$ & $95.5 \%$ & $2.3 \%$ \\
\hline \multirow[t]{2}{*}{ 7. I participate in "parties" online } & 15 & 71 & 2 \\
\hline & $17 \%$ & $80,7 \%$ & $2.3 \%$ \\
\hline \multirow[t]{2}{*}{ 8. I imitate characters from the video games } & 2 & 85 & 1 \\
\hline & $2,3 \%$ & $96,6 \%$ & $1.1 \%$ \\
\hline \multirow[t]{2}{*}{ 9. I like to play adult content games } & 30 & 47 & 11 \\
\hline & $2.3 \%$ & $96.6 \%$ & $1.1 \%$ \\
\hline \multirow[t]{2}{*}{ 10. Video games could be educational } & 69 & 10 & 9 \\
\hline & $78.4 \%$ & $11.4 \%$ & $10.4 \%$ \\
\hline \multirow[t]{2}{*}{ 11. The professor use video games in the class } & 8 & 72 & 8 \\
\hline & $9.1 \%$ & $81.8 \%$ & $9.1 \%$ \\
\hline \multirow[t]{2}{*}{ 12. I would like more educational video games } & 76 & 7 & 5 \\
\hline & $86.4 \%$ & $8 \%$ & $5.7 \%$ \\
\hline \multirow[t]{2}{*}{ 13. I have play educational video games } & 59 & 24 & 4 \\
\hline & $67 \%$ & $27.3 \%$ & $4.5 \%$ \\
\hline \multirow[t]{2}{*}{ 14. Playing video games affects negatively my studies } & 11 & 53 & 23 \\
\hline & $12.5 \%$ & $60.2 \%$ & $26.1 \%$ \\
\hline
\end{tabular}




\section{Results}

\subsection{Descriptive Study}

As seen on Table 4, the students participating in this study said they agree that video games can be seen as a tool for collaborative working to help shape and develop curriculum related to natural sciences, specifically to the human body in general. It can also help in the development of visual arts content along with promoting heuristic and inductive thinking, as well as the visual and retentive memory. They similarly agree to consider that educational video games help in inductive learning and the basic concepts of success and failure, up and down, inside-out, and before-after front-back.

Table 4. Frequency and percentages for the video games and the elementary classroom dimension

\begin{tabular}{|c|c|c|c|c|c|}
\hline & $\begin{array}{l}\text { f. } / \% \\
1\end{array}$ & $\begin{array}{l}\text { f. } / \% \\
2\end{array}$ & $\begin{array}{l}\text { f. } / \% \\
3\end{array}$ & $\begin{array}{l}\text { f. } / \% \\
4\end{array}$ & $\begin{array}{l}\text { f. } / \% \\
5\end{array}$ \\
\hline \multirow{2}{*}{$\begin{array}{l}\text { 15. Learn to work thru cooperation and collaboration using } \\
\text { teamwork. }\end{array}$} & 5 & 16 & 14 & 41 & 12 \\
\hline & $5.7 \%$ & $18.2 \%$ & $15.9 \%$ & $46.6 \%$ & $13.6 \%$ \\
\hline \multirow[t]{2}{*}{ 16. Distinguish the parts of the body. } & 2 & 8 & 27 & 40 & 10 \\
\hline & $2.3 \%$ & $9.1 \%$ & $30.7 \%$ & $45.5 \%$ & $11,4 \%$ \\
\hline \multirow{2}{*}{$\begin{array}{l}\text { 17. Learn the synchronicity between the upper and lower } \\
\text { member of the body }\end{array}$} & 1 & 6 & 27 & 46 & 7 \\
\hline & $1.1 \%$ & $6.8 \%$ & $30.7 \%$ & $52 \%$ & $8 \%$ \\
\hline \multirow[t]{2}{*}{ 18. Recognize primary and secondary colors. } & 2 & 5 & 24 & 43 & 14 \\
\hline & $2.3 \%$ & $5.7 \%$ & $27.3 \%$ & $48.9 \%$ & $15.9 \%$ \\
\hline \multirow[t]{2}{*}{ 19. Development of heuristic thinking (trial-error). } & & 4 & 16 & 49 & 18 \\
\hline & & $4.5 \%$ & $18.2 \%$ & $55.7 \%$ & $20.5 \%$ \\
\hline \multirow{2}{*}{$\begin{array}{l}\text { 20. Autorregulation of individual learning (continuing } \\
\text { evaluation) }\end{array}$} & 1 & 6 & 33 & 37 & 11 \\
\hline & $1.1 \%$ & $6.8 \%$ & $37.5 \%$ & $42 \%$ & $12.5 \%$ \\
\hline \multirow[t]{2}{*}{ 21. Development of inductive thinking. } & 1 & 5 & 28 & 43 & 10 \\
\hline & $1.1 \%$ & $5.7 \%$ & $31.8 \%$ & $48.9 \%$ & $11.4 \%$ \\
\hline \multirow[t]{2}{*}{ 22. Development of visual and retentive memory. } & & 4 & 13 & 50 & 21 \\
\hline & & $4.5 \%$ & $14.8 \%$ & $56.8 \%$ & $23,9 \%$ \\
\hline \multirow{2}{*}{$\begin{array}{l}\text { 23. Understand the concept of success, failure, up-down, } \\
\text { inside-out, front-back. }\end{array}$} & 1 & 4 & 15 & 46 & 22 \\
\hline & $1.1 \%$ & $4.5 \%$ & $17 \%$ & $52.3 \%$ & $25 \%$ \\
\hline
\end{tabular}

\subsection{ANOVA Factor}

Upon various analyzes of variances $(\mathrm{ns}=0.05)$ between the different variables that describe the attitude towards video games and the variables that are included in the primary video games, the following results were gathered: Students who like to play video games if they develop heuristic thinking through trial - error $\left(F=4.052\right.$ and $\left.p=0.021, x^{-}=4.02\right)$.

Similarly, those who read the title game classification before using it develop this type of thinking $(F=4.769$ and $p=$ $0.011, \mathrm{x}^{-}=4.35$ ). The sample shows a like for commenting about video games with friends and acquaintances developing heuristic thinking through trial - error $\left(F=9.851\right.$ and $\left.\mathrm{p}=0.002, \mathrm{x}^{-}=4.25\right)$, and mature visual memory span $\left(\mathrm{F}=4.290\right.$ and $\left.\mathrm{p}=0.041, \mathrm{x}^{-}=4.21\right)$ and more awareness about the concepts of success - failure, up - down, in - out, before - after and before - after $\left(F=9.953\right.$ and $\left.p=0.002, x^{-}=4.30\right)$, contrary to those who do not comment or do not know or no answer.

The students that participated in forums or chats about video games recognize better the primary and secondary colors $\left(\mathrm{F}=4.152\right.$ and $\left.\mathrm{p}=0.019, \mathrm{x}^{-}=4.00\right)$, develop inductive thinking $\left(\mathrm{F}=5.908\right.$ and $\left.\mathrm{p}=0.004, \mathrm{x}^{-}=4,50\right)$, and visual and retentive memory $\left(\mathrm{F}=8.326\right.$ and $\left.\mathrm{p}<0.001, \mathrm{x}^{-}=4.00\right)$ versus those who don't participate or do not know or didn't answered this question. 
People participating in online "parties" develop more visual and retentive memory $\left(\mathrm{F}=3.489\right.$ and $\left.\mathrm{p}=0.035, \mathrm{x}^{-}=4.33\right)$ compared to those who don't participate or do not know or didn't answer this question. The students who expressed that they do not imitate characters in video games develop inductive thinking $\left(\mathrm{F}=4.580\right.$ and $\left.\mathrm{p}=0.013, \mathrm{x}^{-}=3.69\right)$, along with visual and retentive memory $\left(\mathrm{F}=6,003 \mathrm{p}=0.004, \mathrm{x}^{-}=4.05\right)$ in contrast to those who don't like or do not know or didn't answer. Students who expressed that like to play games with adult content developed more heuristic thinking through trial - error $\left(\mathrm{F}=3.183\right.$ and $\left.\mathrm{p}=0.047, \mathrm{x}^{-}=4.21\right)$, and visual and retentive memory $(\mathrm{F}=3.803$ and $\mathrm{p}=$ $0.026, \mathrm{x}^{-}=4.30$ ) compared with those who stated that they do not like playing these games or those who do not know or show no answer.

The sample shows that video games can be educational and students learn better using collaboration and teamwork (F $=3.145$ and $\left.\mathrm{p}=0.045, \mathrm{x}^{-}=3.58\right)$, and developed heuristic thinking through trial - error $\left(\mathrm{F}=5.156\right.$ and $\mathrm{p}=0.008, \mathrm{x}^{-}=$ 4.06) than those who believe that video games cannot be educational or do not know or no answer. People who say they wish there were more educational video games developed heuristic thinking mostly through trial - error $(\mathrm{F}=4.650$ and $\left.\mathrm{p}=0.012, \mathrm{x}^{-}=4.01\right)$.

On the other hand, reading specialized magazines about video games, online reading about all new games coming out, the use by teachers of video games in class, ever playing educational games or having a negative opinion about the use of video games reveal no significant differences in the macro dimension video games in elementary school, in other words, analysis of variance or ANOVA does not reflect relevant results.

\section{Discussion and Conclusions}

The integration of technology in the classroom in any educational level is a reality today. However there is certain disbelief or negativity in regards to the use of video games during the student formation without giving the strategy an opportunity. As we can observe throughout this study, future educators indicate to have a tendency to introduce video games in the curriculum. Following the objectives in this research, we can see that objective 1 (determine that video games are elements that can modulate behaviors, affecting belief systems, values, attitudes and skills), is considered by the future educators as a mechanism to modulate the behaviors and personalities in an educational use without supervision. They are determined by the themes and readings made on the subject in magazines and digital media.

In regards to objective 2 (clarify if video games are a technological resource that could help in the comprehension of curricular content), we have seen throughout this investigation that the students in this study similar to those carried out by Quintanal (2013) and Herrero, del Castillo, Monjalet, García-Varela, Czech \& Gómez (2014) reflect the same results, the use of video games makes more enjoyable curriculum development training. On ther other hand, objective 3 (determine whether methodological systems must use them in the classroom to improve the classroom climate/atmosphere.) just like the results of Anneta, Minogue, Holmes. \& Cheng (2009), the students enjoy their classes more and feel a greater level of commitment, motivation and intellectual intensity during the learning process supported by these resources.

Finally, objective 4 (determine whether education should look at them from an educational and pedagogical perspective.) confirms the information provided by the Project Tomorrow (2008). A total of $65 \%$ of the professors consulted were interested in including video games in the classroom, and $50 \%$ would be interested to learn on how to incorporate them as a teaching strategy. As we see both male and female teachers with varying degrees of teaching experience matching those teachers in training who participated in this work. Similarly the work done by Kenritchi, Hurumi \& Bai (2010) confirms our objective.

\section{References}

aDeSe. (2012). A'12. Anuario de la industria del videojuego. Retrieved from $\mathrm{http}: / /$ www.adese.es/anuario2012/ANUARIO_ADESE_2012.pdf

Alamri, A., Hassan, M. M., Hossain, M. A., Al-Qurishi, M., Aldukhayyil, Y., \& Hossain, M. S. (2014). Evaluating the impact of a cloud-based serious game on obese people. Computer in Human Behaviour, 30, 468-475.

Anneta, L. A., Minogue, J., Holmes, Shawn Y., \& Cheng, M-T. (2009). Investigating the impact of videogames on high schools student's engagement and learning about generics. Computer \& Education. 53, 74-85.

Barendiegt, W., \& Bekker, T. M. (2011). The influence of the level of free-choice learning activities on the use of on educational computergame. Computer \& Education, 56, 80-90. 
Contreras, R. S. (2013). Acercamiento a las características de los videojuegos y sus beneficios en el aprendizaje. II Congreso Internacional de videojuegos y educación. Cáceres, Octubre de 2013. Retrieved from http://repositori.uvic.cat/xmlui/bitstream/handle/10854/2753/artconlli_a2013_contreras_ruth_acercamiento_car acteristicas_videojuegos.pdf? sequence $=1$

Del Moral, E., \& Villaluestre, L. (2014). Instrumentos para la evaluación y análisis de videojuegos desde una perspectiva educativa. En F.I. Revuelta, M. R. Fernández, M. I. Pedrera \& J. Valverde (Coords.). Actas del II Congreso Internacional de Videojuegos y Educación. (pp. 92-104).Cáceres: Bublokpublishing.

Garrido, J. M. (2013). Videojuegos de estrategia: algunos principios para la enseñanza. Revista Electrónica de Investigación Educativa, 15(1), 62-74.

Gros, B. (2002). Nuevos medios para nuevas formas de aprendizaje: el uso de los videojuegos en la enseñanza. Revista Red Digital, 3. Retrieved from http://reddigital.cnice.mec.es/3/firmas/firmas_gros_ind.html

Hamlen, K. R. (2011). Children's choices and strategies in videogames. Computer in Human Behaviour, 27, 532-539. http://dx.doi.org/101016/j.chb.2010.10.001

Herrero, D., del Castillo, H., Monjelet, N., García-Varela, A. B., Checa, M., \& Gómez, P. (2014). La teoría de la evolución y la selección natural: aprender a través del juego y la reflexión. New Approaches in Educational Research, 3(1), 26-33.

Hobbs, R. (2010) Digital and media literacy: a plan of action. USA: The Aspen Institute. Retrieved from http://www.knightcomm.org/digital-and-media-literacy/from-report-to-action/

Kebritchi, M., Hirumi, A., \& Bai, H. (2010). The effects of modern mathematics computer games on mathematics achievement and class motivation. Computer \& Education, 55, 427-443.

Kim, Y., \& Ross, S. D. (2006). An exploration of motives in sport videogames. International Journal of Sports Marketing Sporrship, 8(1), 34-46.

Kirriemuir, J., \& McFarlone, A. E. (2003). Literature review in games report. Bristol, Nesta Futurelab.

LOGSE, Ley Orgánica 1/1990, de 3 de octubre de 1990, de Ordenación General del Sistema Educativo. Retrieved from http://www.boe.es/buscar/doc.php?id=BOE-A-1990-24172

LOE, Ley Orgánica 2/2006, de 3 de mayo, de Educación Retrieved from: http://www.boe.es/boe/dias/2006/05/04/pdfs/A17158-17207.pdf

LOMCE, Ley Orgánica para la Mejora de la Calidad Educativa. (2013). Retrieved from http://www.boe.es/boe/dias/2013/12/10/pdfs/BOE-A-2013-12886.pdf

Marín García, J. A. (2011). Pasos previos en SPSS para la validación de escalas. Universitat Politécnica de Valencia (UPV). Disponible en: https://www.youtube.com/watch?v=28iGvEpmfXw

Marín, V., \& Maldonado, G. A. (2014) Propuesta de desarrollo curricular en la etapa de primaria a través de los videojuegos. Actas II Congreso Virtual Internacional sobre Innovación Pedagógica y Práxis Educativa. Sevilla, marzo de 2014. En prensa.

Marín, V. (2012a). El ayer y el hoy de los videojuegos y juegos digitales. En V. Marín (coord.). Los videojuegos y los juegos digitales como materiales educativos (pp. 19-33). Madrid: Síntesis.

Marín, V. (2012b). Investigando sobre el potencial psicosocioeducativo de los videojuegos y juegos digitales. (pp. 193-218). En V. Marín (coord.). Los videojuegos y juegos digitales como materiales educativos. Síntesis: Madrid.

Marín, V., \& García, Ma D. (2005). Los videojuegos y su capacidad didáctico formativa. Pixel Bit, Revista de Medios y Educación. 26, 113-119.

Marín, V., Muñoz, J. M., \& Sampedro, B. E. (2013).Trabajando con videojuegos el currículo de grado de Educación Infantil. En E. Corbi, E, López, F. M. Sirignano, J. L. Sarasola \& J. González (coord.). II Seminario Científico Internacional sobre Formación Didáctica con Tecnologías Web 2.0. (pp. 148-156). Sevilla: AFOE.

Marín, V., Ramírez, A., \& Cabero Almenara. J. (2010). Los videojuegos en el aula de primaria. Propuesta de trabajo basado en competencias básicas. Comunicación y Pedagogía, Primeras Noticias, 244, 13-18.

Mateo, J. (2012). La investigación ex post-facto. En Bisquerra, R. (coord.). Metodología de investigación educativa. (pp. 195-229). Madrid, La Muralla. 
Mortaraa, M., Catalanoa, Ch. E., Bellottib, F., Fiuccic, G., Houry-Panchettid, M., \& Petridise, P. (2014). Learning cultural heritage by serious games. Journal of Cultural Heriage. 15, 318-325.

Pérez, R., García, J. L., Gil, J. A., \& Galán, A. (2009). Estadística aplicada a la educación. Madrid, Pearson Educación y UNED.

Proyect Tomorrow. (2008). Speak up 2007 for students, teachers, parents and administrators. Retrieved from http://www.tomorrow.org/docs/national\%20findings\%20speak\%20up\%202007.pdf

Quintanal, F. (2013). Aplicación de minijuegos en Física y Química de Bachillerato. Historia y Comunicación Social, $18,411-420$.

Raña, J. C. (2003). Los microciberjuegos y el aprendizaje de las ciencias sociales: el mundo de JAVA. Revista Electrónica de Investigación y Evaluación Educativa, 9(2), 236-246.

Watson, W., Christopher, J. M., \& Harris, C. A. (2011). A case study of the in-class use of a videogame for teaching high school. Computers \& Education, 56, 466-476.

Williamson, B. (2009). Computer games, schools and Young people. A report for educators on wing games for learning. Retrieved from http://www2.futurelab.org.uk/resources/documents/project_reports/becta/Games_and _Learning_educators_report.pdf 